\title{
Sustainability of Palm Biodiesel in Transportation: a Review on Biofuel Standard, Policy and International Collaboration Between Malaysia and Colombia
}

\author{
Mohd Nur Ashraf Mohd Yusoff ${ }^{1,2} \cdot$ Nurin Wahidah Mohd Zulkifli ${ }^{1}$. Nazatul Liana Sukiman ${ }^{1,2}$ • Ong Hwai Chyuan ${ }^{3}$. \\ Masjuki Haji Hassan ${ }^{4}$. Muhammad Harith Hasnul ${ }^{1}$ • Muhammad Syahir Amzar Zulkifli ${ }^{1}$. \\ Muhammad Mujtaba Abbas ${ }^{1,5}$. Muhammad Zulfattah Zakaria ${ }^{1}$
}

Received: 30 January 2020 / Accepted: 13 July 2020 / Published online: 22 July 2020

C) Springer Science+Business Media, LLC, part of Springer Nature 2020

\begin{abstract}
Biodiesel is gaining prominence as a superior alternative source of energy to replace petroleum-based fuel in transportation. As of today, the biodiesel market continuous to rise up as the biofuel has been introduced to more than 60 countries worldwide. The aim of the present review is to highlight on the scenario of the biofuel implementation in transportation sector towards sustainable development in Colombia and Malaysia. Colombia serves as an ideal comparative case for Malaysia in terms of biodiesel development since the country is the main palm oil producer in Latin America region and the pioneer in bioethanol industry. The first section shows an overview on the biodiesel as an alternative fuel in transportation. The next section will focus on a comparative study between Malaysia and Colombia biodiesel sector in terms of energy supply, resource, production and consumption, standards, techno-economic cost and their biodiesel policies. A comprehensive review was studied to discuss on the sustainability of palm cultivation and biodiesel, impact of palm industry and biodiesel policy in transportation sector and potential international collaboration between Malaysia and Colombia to improve their existing policies, strategies and blueprints related to the palm biodiesel industry, thus overcoming the challenges when dealing with global energy issue.
\end{abstract}

Keywords Alternative fuel $\cdot$ Technology development $\cdot$ Socio-economy $\cdot$ Deforestation

\section{Nomenclature}

ATM Malaysia Armed Forces

b/d Barrels per day

Mohd Nur Ashraf Mohd Yusoff

ashraf@um.edu.my

$\triangle$ Nurin Wahidah Mohd Zulkifli nurinmz@um.edu.my

1 Department of Mechanical Engineering, Faculty of Engineering, 50603, Kuala Lumpur, Malaysia

2 Centre for Latin America Studies, University of Malaya, 50603 Kuala Lumpur, Malaysia

3 School of Information, Systems and Modelling, Faculty of Engineering and Information Technology, University of Technology Sydney, Sydney, Australia

4 Department of Mechanical Engineering, Faculty of Engineering, International Islamic University Malaysia, Kuala Lumpur, Malaysia

5 Department of Mechanical Engineering, University of Engineering and Technology, City Campus Lahore, Lahore, Pakistan

$\begin{array}{ll}\mathrm{CO}_{2} & \text { Carbon dioxide } \\ \text { COP } & \text { Colombian peso } \\ \text { COP21 } & \text { 2015 United Nations Climate } \\ & \text { Change Conference } \\ \text { CPO } & \text { Crude palm oil } \\ \text { CPOPC } & \text { Council of Palm Oil Producing Countries } \\ \text { DBKL } & \text { Kuala Lumpur City Hall } \\ \text { EP } & \text { European Parliament } \\ \text { EU } & \text { European Union } \\ \text { GDP } & \text { Growth domestic product } \\ \text { GHGs } & \text { Greenhouse gases } \\ \text { IPCC } & \text { Intergovernmental Panel on Climate Change } \\ \text { KtCO } 2 \text { eq } & \text { Kiloton carbon dioxide equivalent } \\ \text { MAA } & \text { Malaysian Automotive Association } \\ \text { MPOB } & \text { Malaysian Palm Oil Board } \\ \text { MME } & \text { Ministry of Mines and Energy } \\ \text { MSPO } & \text { Malaysian Sustainable Palm Oil } \\ \text { NBP 2006 } & \text { National Biofuel Policy of Malaysia } \\ \text { PDRM } & \text { Royal Malaysia Police } \\ \text { RED } & \text { Renewable Energy Directive } \\ \text { RSPO } & \text { Roundtable on Sustainable Palm Oil }\end{array}$




$\begin{array}{ll}\text { SIRIM } & \begin{array}{l}\text { Standard and Industrial Research } \\ \text { Institute of Malaysia }\end{array} \\ \text { SLDB } & \begin{array}{l}\text { Sabah Land Development Board } \\ \text { SST }\end{array} \\ \text { Sales and services tax } \\ \text { UNFCCC } & \begin{array}{l}\text { United Nations Framework } \\ \text { Convention on Climate Change }\end{array} \\ \text { UPME } & \text { Unit of Mining and Energy Planning } \\ \text { VAT } & \text { Value added tax }\end{array}$

\section{Introduction}

Today more than ever before, massive climate change such as global warming is the main issue that is often highlighted by the world communities. The rapidness of sea ice melting and the rise of sea level which resulted from global warming are currently happening in our ecology. According to the Intergovernmental Panel on Climate Change (IPCC), the average global temperature is forecasted to rise by as much as $10.4^{\circ}$ F over the next century [1]. The scientists believe that the rise of global temperature is largely due to the rapid accumulation of greenhouse gases (GHGs) such as carbon dioxide $\left(\mathrm{CO}_{2}\right)$ produced by human activities. In addition, the transportation sector has contributed in almost $14 \%$ of the 2010 total global GHG emissions [2]. In fact, the increase in the number of vehicles fuelled with petroleum-based fuel also results in the depletion of fossil fuel reserves. Approximately 50\% of the total fossil fuel consumption relates to the energy needs of the transport sector [3]. These fossil fuels are slowly becoming obsolete and anticipated to scarce within the next decades [4].

With regard to these problems, numerous alternative fuels have been discovered to replace fossil fuels, while the demand for energy source will continue to increase day by day. In view of the current urgency plan to reduce the net GHG emissions in transportation, biofuels are the most promising alternative that have been studied to replace fossil fuels to be utilized as the whole transportation energy supply system, besides solar and fuel cell. The biofuel industry is continuously coming up with various sources, utilizing vegetation, biomass as well as microorganisms, which can be leveraged for biodiesel and bioethanol production for transportation system. Southeast Asia countries, such as Malaysia, Indonesia, Thailand and Vietnam, are endowed with plenty of natural resources, e.g. palm oil, rice husk, etc. which could significantly provide a continuous supply of biofuels to meet the world's energy demand. However, the lack of technical expertise, government policies and technology experience in this region will provide challenges in strengthening the biofuels sector. Therefore, it is important for these countries to identify the impending and subsequent challenges to stay in the forefront of sustainable development.

Latin America countries, e.g. Brazil and Colombia, are the world-class biofuel producer, which has a vast experience in producing bioethanol from sugarcane as an alternative liquid biofuel widely since the 1970s. The supportive government policies and technological advances have led the countries to become the forefront in the world's biofuel sectors and become a policy model to neighbouring countries in Latin America. The growing biofuel market in the region is mainly triggered by the success of the Brazilian bioethanol production for both domestic market and export. National policies, agricultural structures and practices, labour conditions, environmental aspects, land use competition and strategies on biofuels and the enforcement of existing laws are several important factors which influence the sustainability of biofuels in the region [5].

In this study, Colombia has been chosen for this review based on the fact that there is a little information available stated that its palm biodiesel industry has been considered as the main palm oil producer in Latin America region and the pioneer of bioethanol industry. Therefore, Colombia serves as an ideal comparative case for Malaysia in terms of biodiesel development. A comprehensive review is studied extensively to discuss the scenario of biofuel implementation in transportation sector towards sustainable development in both respective nations. This review also will help to point out several opportunities for international collaboration amongst the nations towards achieving the global quest for a sustainable development in the transportation sector.

\section{Biofuel as an Alternative Fuel}

Biofuels offer many priorities, including renewability, biodegradability, sustainability and carbon neutrality. Therefore, it holds great promise to solve environment-related problems, i.e. greenhouse effect as well as air pollution. The two most common liquid biofuels are bioethanol and biodiesel, which are widely used as replacements to hydrocarbon transportation fuels like gasoline and diesel, respectively. Biofuels are also available in other forms, i.e. solid fuel (e.g. bio-char) and gas fuel (e.g. hydrogen and methane). The utilization of biofuels as an alternative fuel is not a new concept as long as there are vehicles on the road. Samuel Morely has developed an engine fuelled with ethanol in 1826 and Henry Ford built a Model T engine to run on ethanol in 1908 [6]. Ethanol is the most widely used biofuel today for gasoline engine. Conventional ethanol (first generation), e.g. starch and sucrose-rich materials, can be produced via alcoholic fermentation. Meanwhile, advanced ethanol (second generation) is produced from lignocellulosic material, e.g. agricultural waste undergoes additional pre-treatment process before it is hydrolysed and fermented into ethanol. Besides that, ethanol can be used in its pure form (neat), as a blend with gasoline or as a fuel for fuel cells. Brazil and the USA together are accounted for $85 \%$ of the world's total fuel ethanol production [7]. In Brazil, ethanol derived from sugar cane claims $40 \%$ of the light fuel market and has contributed the country to end its dependence on imported oil. 
On the other hand, biodiesel became popular as the replacement to petroleum-based diesel in transportation. The biodiesel blend was introduced worldwide for more than 60 countries including Indonesia (B20), the USA (up to B10 in some states), Colombia (B2-B10), Argentina (B10), Brazil (B10), France (B8) and Malaysia (B10). Biodiesel is a vegetable oilor animal fat-based diesel fuel consisting of long-chain alkyl (methyl, ethyl or propyl) esters. Biodiesel can be derived from edible oils (palm [8], soybean [9], corn and sunflower [10]), non-edible oils (Jatropha curcas, Calophyllum inophyllum, Ceiba pentandra [11] and Mahua [12]), algae oils (Chlorella, spirulina and pond water algae) [13], waste vegetable oils [14] and animal fats (tallow, lard, yellow grease and chicken fat) [15].

However, the extensive utilization of food-based crops for biofuel production has attracted some criticisms. The global food crisis occurred very badly from 2007 to 2008 due to the failure of the world food system to preserve food security. It was claimed that the conversion of these food crops to biofuel would significantly increase the food prices, consequently affecting the lives of the poor, especially in developing countries. The oil crops such as palm oil, soybean, rapeseed, sunflower and peanut are renewable sources of oils and fats that can be used either as edible foodstuffs or as industrial feedstocks. Malaysia as the main palm oil producer is not spared from this negative criticism as the palm oil has fallen trap into this debate too. Palm oil is indeed the largest vegetable oil, by dominating more than a quarter of the total global oil and fat production, and perceived as the most promising for biodiesel feedstocks. Nonetheless, the extensive replacement of rapeseed and corn oil as biofuel feedstocks in Europe and the USA, respectively, is the main reason behind the shortage of soybean and rapeseed as the source of oils and fats in the world market [16]. As we will now see, palm oil is far more efficient than all other oil crops in terms of oil yield, land usage and asset deployment [17]. This efficiency is reflected in the pricing of palm oil, which is almost invariably considerably cheaper than its rivals. Therefore, palm oil has been proven the most sustainable and economically feasible source of food and biofuel in the world market, thus satisfying both demands simultaneously rather than engaging in priority debate.

\section{Energy Supply in Malaysian and Colombian Transportation Sector}

\section{Malaysia}

Malaysia is situated within Southeast Asia and has two distinct regions. The western region includes the Peninsular Malaysia, while the eastern region is where Sabah and Sarawak are located. It has a total landmass of $330,803 \mathrm{~km}^{2}$ and consists of 13 states and three federal territories. Malaysia is the fourth largest economy and the second largest oil and natural gas producer in Southeast Asia. Therefore, energy industry is the most important sector of Malaysia's growth economy which accounted approximately $20 \%$ of the total growth domestic product (GDP) in the recent years [18]. Malaysia's economy has been fuelled by its energy resources, both renewable and non-renewable, and rapid development across the country. Prior to that, Malaysia has spent heavily in refining activities by gearing up its capacity to become a regional oil and natural gas storage, trading and development hub that can compete within Asia. To date, Malaysia has six refineries with a capacity of about 596,700 barrels per day (b/d) and is currently developing a new refinery, Pengerang Integrated Petroleum Complex in Johor, with a capacity of 300,000 b/d as a part of Malaysia's desire to compete with the oil refinery and storage hub in Singapore [18].

Malaysia is focusing on securing energy by diversifying energy supply portfolio as part of the country's economic transformation program to leverage its useful resources to become Asia's top energy players by 2020. Natural gas and petroleum as well as other liquids are the main energy sources in the country with their share of 41 and $33 \%$, respectively, in 2016 [19]. The government emphasizes fuel diversification through investments in renewable energy, i.e. biodiesel, solar, biomass and biogas, to sustain the economic growth and heavy reliance on petroleum and natural gas. Besides that, the transportation sector is the largest energy consumer in 2016 with its share of $42 \%$ from the final energy consumption to register at 24,004 ktoe [19]. However, the performance of the transportation sector declined in 2015 by $3.7 \%$ from the previous year due to the economy slowdown during that respective year. In fact, according to the Malaysian Automotive Association (MAA), the sales of new vehicles in Malaysian market in 2016 dropped from 666,674 units to 580,124 units in 2015. The sales dropped further to 576,635 units in year 2017. This is due to the depreciation of Malaysian ringgit against US dollar, high living cost, higher cost of newer vehicles and difficulties to receive loans. Gasoline-powered engines such as motorcycles, cars, light trucks and boats are the dominant vehicles in Malaysia, which accounted about $80 \%$ of the market sales [20]. Meanwhile, diesel-powered engines such as pick-ups, buses and trucks are slowly growing in the country. In fact, the total gasoline and diesel utilization increased tremendously from 2009 to 2017, with values of 3622 to 7686 million litres and 3568 to 5712 million litres, respectively [21].

\section{Colombia}

The Republic of Colombia is situated in the northwest of South America, with territories in Central America. It has a total landmass of $1,141,748 \mathrm{~km}^{2}$ and comprises 32 
departments, with the capital in Bogota. Colombia is the second largest economy in Middle America and the fourth largest economy in Latin America. The country has experienced a historic economic boom over the last decades; in fact, it was the Latin America's fifth largest economy in 1990 and it became the fourth in Latin America by 2015. Colombia is a country gifted with numerous fossil fuels and natural resources, reflected in an energy matrix rich in petroleum reserves, natural gas reserves, coal reserves and extensive hydroelectric resources. Oil is the main source for Colombia's total energy consumption in 2017 with its share of 39\%, followed by hydroelectric power, natural gas and coal with their shares of 30, 20 and 9\%, respectively [22]. The oil production increased vigorously in 2007 to 2013 due to the increase in new exploration and development, spurred by new reforms in energy sector regulatory by 2003. As evidence, Colombia has produced more than one million $b / d$ of petroleum and other liquids in 2015, with an average increase of $11 \%$ from 2008 . The country has utilized $293,000 \mathrm{~b} / \mathrm{d}$; the rest is exported to foreign countries, mainly to the USA with total exports of 330,000 b/d in 2017. Colombia's total petroleum and other liquids production is continuously declining in the following 2 years, with an average production of $879,000 \mathrm{~b} / \mathrm{d}$ in 2017 [23].

Similar to Malaysia, transportation sector is the largest energy consumer in Colombia with its share of $45 \%$ from the final energy consumption [24]. In addition, the sector has emerged as one of the driving forces of the Colombian economy, which contributed 7\% of the total GDP in Colombia in 2017. As of 2015, road transport is the most preferred transport mode for passenger movement in Colombia with its share of $84.4 \%$, followed by air, rail and maritime with their shares of $15.2,0.3$ and $0.1 \%$, respectively. For cargo transportations, road and maritime are the most preferred transport modes with shares of 46.3 and $37.1 \%$, respectively [25]. According to Unit of Mining and Energy Planning (UPME) of MME, demands for diesel and gasoline will rise for the next 10 years mainly due to the growth of Colombian economy. Unlike Malaysia, diesel-powered engines are the most used vehicles in Colombia. In fact, the total diesel and gasoline used increased from 2009 to 2017, with values of 6294 to 8630 million litres and 4402 to 6818 million litres, respectively [26].

\section{Biodiesel Resource, Production and Consumption in Malaysia and Colombia}

Many countries are stimulating the production of biofuels to replace the non-renewable source of fossil fuel dependency. Malaysia and Colombia are considered gifted because these two countries can deal with their internal consumption due to sufficient cultivated land area and high biophysical suitability for crops to grow efficiently.
Oil palm tree (Elaeis guineensis) as presented in Fig. 1 is a tropical plant that can grow well on lowland with humid condition. It belongs to the Arecaceae family, which originated from West Africa before being widely distributed as an agricultural crop in Indonesia, Malaysia, Sri Lanka and the West Indies. The average oil yield for oil palm is about 4 to 5 million tons of oil per hectare annually [27]. Palm oil is the most productive vegetable oil crop with the best yield per hectare in comparison with other crops. It has 4 to 6 times higher yield compared with those edible oils, i.e. cottonseed, sunflower seed, peanut, soybean and rapeseed as presented in Fig. 2 [28]. The two main products produced from oil palm fruit includes palm oil and palm kernel oil, which are extracted from the fruit mesocarp and endosperm (kernel), respectively. Palm oil has the total saturated and unsaturated fatty acid content of 49.5 and $50.5 \%$, respectively, of which palmitic (C16:0), oleic (C18:1) and linoleic (C18:2) acids are the major constituents (42.7, 39.4 and 10.6\%, respectively) [29]. High amounts of saturated fatty acid and monounsaturated fatty acid indicate that crude palm oil has good oxidative stability. However, high saturation degree also results in poor low temperature characteristics.

\section{Malaysia}

Commercial oil palm cultivation in Malaysia began in 1917 in Tennamaram Estate, Selangor. In the 1960s, the cultivation of palm oil rapidly increased under the Malaysian government's agricultural diversification program, which aims to diversify its agricultural land whilst reducing the country's economic dependency on rubber and tin. The government also introduced land settlement schemes for planting oil palm in the late 1960s to eradicate poverty for the landless farmers and smallholders. The total planted area of Malaysia palm oil crops increased gradually from 2009 to 2018 , from 4.6 to 5.85 million hectares, respectively [30,31]. It has become the most important commodity crop in Malaysia. Currently, the crops that are being planted are the tenera variety, a hybrid between the deli dura and pisifera, which yields about 4 to 5 tons of crude palm oil (CPO) per hectare and around 1 ton of palm kernels.

Palm oil plays a significant role in expanding the world's production and consumption of oils and fats, surpassing soybean, rapeseed and sunflower oil. The global production of palm oil is predominantly dominated by Indonesia and Malaysia, which together supply about $84 \%$ of the total palm oil. This is followed by Thailand, Colombia and Nigeria with small shares of 4,2 and $1 \%$, respectively. Based on the consumption, the largest consumers of palm oil are India, the European Union and China with nearly $50 \%$ of the total world exports.

The Malaysian government intended to promote palm oil production and the utilization of palm-derived biodiesel especially in transportation and industrial sector under Malaysia's National Biofuel Policy 2006 (NBP). The total CPO 
Fig. 1 Oil palm tree (Elaeis guineensis) and oil palm fruit mesocarp

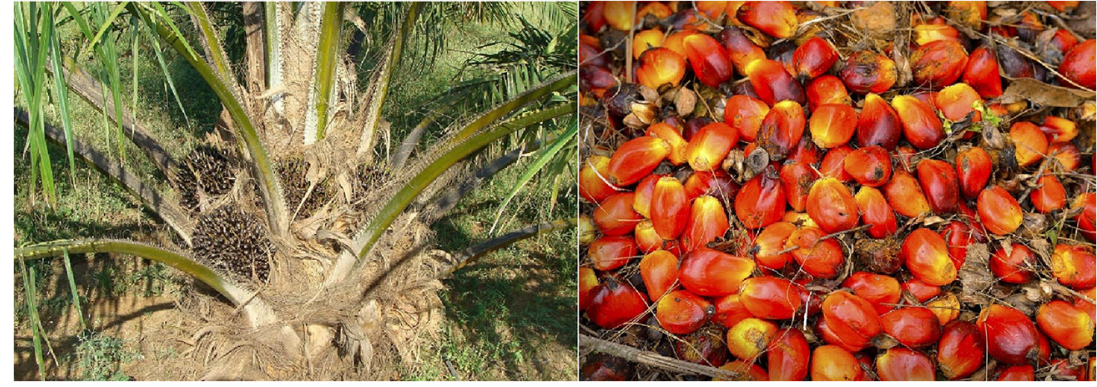

production in Malaysia increased from 17.56 million tons in 2009 to 19.8 million tons in 2019 [30, 31]. However, it is expected that the Malaysian palm oil production will drop by $1 \%$ in 2020 from a year earlier. This is due to the impact of dryer weather in the middle of 2019 and the country's lockdowns to prevent the spread of coronavirus. A significant growth of palm oil production is projected with 2.3 million tons in the year 2028 [32]. In terms of consumption, Malaysia's domestic consumption made up only a fraction of its total palm oil output, which is around 3.7 million metric tons; thus, the industry easily met the local oil and fat demands, leading to the excess being exported. Based on the production in 2018 , more than $84 \%$ of the total CPO was exported to several countries such as India (15.2\%), EU (11.6\%), China (11.3\%), Pakistan (7\%) and others [33]. The rest of the CPO was being processed into biodiesel or food products such as cooking oil and margarine.

The Malaysian production of palm biodiesel has steadily increased since 2014 with 611 million litres to 907 million litres in 2017 [21]. It was expected that the production of biodiesel in 2019 is projected at 1.56 billion litres with capacity use of $67 \%$. Today, there are 16 palm biodiesel refineries that are still operating in the country, i.e. Johor (5), Selangor (5), Perak (2), Sabah (2), Pahang (1) and Sarawak (1). However, the production of biodiesel in Malaysia is

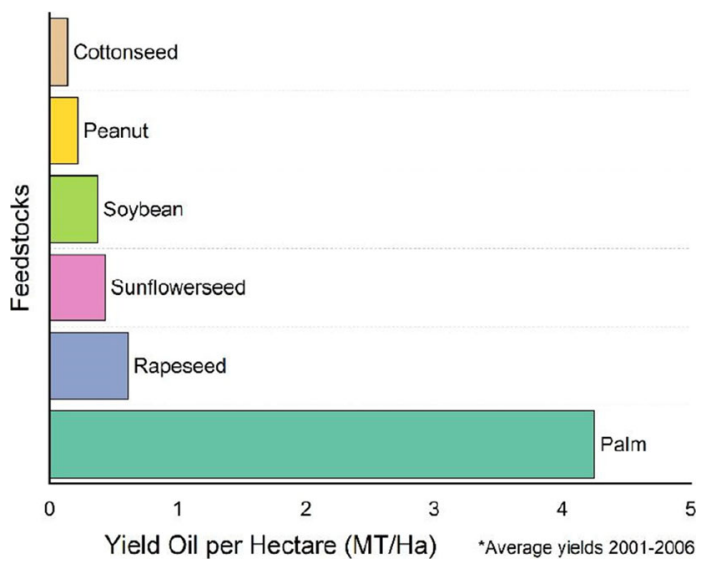

Source: The source data were obtained from Commodity Intelligence Report USDA.

Fig. 2 Comparison yields of vegetable oilseed crops [28] significantly low as the total palm biodiesel production in 2017 only produce $40 \%$ of its full annual capacity which is 2.34 billion litres. Therefore, there is no licence to be issued for new refinery plant due to overcapacity of the industry.

Besides that, the total consumption of biodiesel for transportation sector in Fig. 3 is significantly increased from 516 million litres $(562,000$ metric tons of CPO use for fuel) in 2014 to 640 million litres $(834,000$ metric tons of CPO use for fuel) in 2017 [21]. However, the delay of B10 mandate in 2015 and 2016 caused a reduction of biodiesel consumption with the values of 456 and 630 million litres, respectively. Besides palm oil, non-edible crop such as Jatropha curcas is being used as the feedstock for biodiesel production in Malaysia which has been developed by the government and non-government agencies such as Sabah Land Development Board (SLDB) and Bionas Agropolitan Technology Corridor Development Berhad.

\section{Colombia}

Colombia began its commercial oil palm cultivation in 1945 when the US-based United Fruit Company established a plantation in the banana zone of the Magdalena department. Palm plantation has the most potential to be the axis to achieve Colombian economic development. The palm crops are cultivated moderately for the next 30 years since its commercialization but only focus on the local markets. The Colombian government is also promoting palm oil cultivation to replace the cultivation of illicit drug crops such as opium poppy and cocaine. Besides that, the land available for the agriculture sector in Colombia is five times higher than in Malaysia. The palm crops are present in four areas, including Central, North, East and Southwest, which covers 122 municipalities in 19 departments across the country.

Colombia is the first producer of palm oil in Latin America and currently the fourth producer in the world, following Indonesia, Malaysia and Thailand. The total $\mathrm{CPO}$ production in Colombia has increased from 0.8 million tons in 2009 to more than 1.6 million tons in 2019 . The palm oil production in Colombia is expected to expand more to 2.0 million tons in 2028 mainly for domestic and regional markets [32]. The consumption of palm oil in Colombia is only dependant on the local production to meet the country's blend mandate of biodiesel. The domestic consumption of palm oil was around 
Fig. 3 Production and consumption of palm biodiesel in Malaysia and Colombia, year 2009-2018. Source: The source data for Malaysia is obtained from USDA Gain Report MY8010 [21], which is sourced from Malaysian Palm Oil Berhad (MPOB). The source data for Colombia is obtained from USDA Gain Report CO1811 [26], which is sourced from the National Federation of Palm Oil Growers (FEDEPALMA)

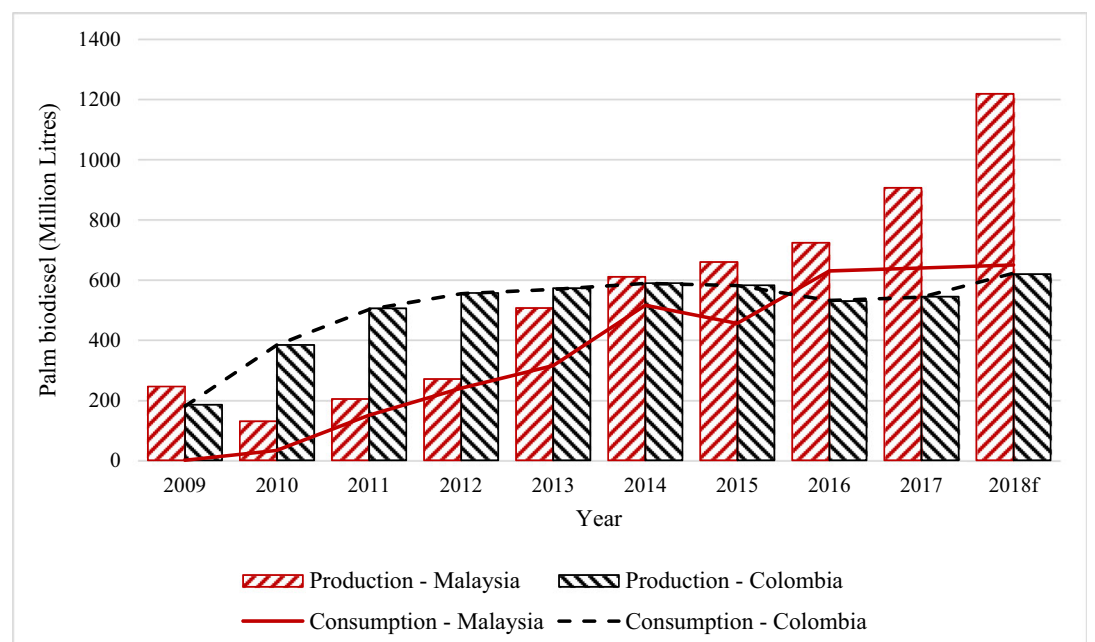

Source: The source data for Malaysia is obtained from USDA Gain Report MY8010 [21], which is sourced from Malaysian Palm Oil Berhad (MPOB). The source data for Colombia is obtained from USDA Gain Report CO1811 [26], which is sourced from the National Federation of Palm Oil Growers (FEDEPALMA).
1.16 million metric tons in 2019. Unlike Malaysia, Colombia does not export biodiesel to other countries. In 2017, palm oilbased biodiesel production was fully supplied by eight plants with a production capacity of 700 million litres. However, less palm oil biodiesel were produced in 2016 and 2017 with respect to the previous years with 530 and 545 million litres, respectively, because of difficult weather conditions. Besides palm oil, Colombia also produces other crops for biodiesel that are developing industrially such as coconut, castor, avocado, Jatropha curcas, rapeseed, soybean and algae oil with good yields and quality.

Figure 3 shows the production and consumption of palm biodiesel in Malaysia and Colombia from 2009 to 2018. It can be seen that the production and consumption of palm biodiesel in Malaysia were rapidly increased from 2010 to 2018. This is due to the higher demands of palm biodiesel from major customers, i.e. India, China, Peru and EU. The production of biodiesel in 2019 is also projected to remain strong as a result of the new B10 biodiesel mandate replacing B7, thus increasing the local consumption of palm oil. Meanwhile, the production and consumption of palm biodiesel in Colombia remained stable from 2012 to 2018 for domestic use only.

\section{Biodiesel Standards and Current State of Physicochemical Properties of Palm Biodiesel in Malaysia and Colombia}

The biodiesel standards are vital for its commercialization and market introduction. Therefore, it is necessary to have a good standard to regulate the quality and give assurance to the engine manufacturers and end users. The quality standards for palm biodiesel in Malaysia were established by the Standard and Industrial Research Institute of Malaysia (SIRIM Berhad), where the MS 2008:2008 was published in 2008, mainly based on the European Standards (EN 14214) with some minor modifications suggested by the Technical Committee on Petroleum Fuels [34]. Meanwhile, the technical specifications for biodiesel in Colombia is regulated by the Colombian Biodiesel Standard (NTC 5444), mainly based on the US Standards. Table 1 shows the comparison of the standard specification for biodiesel fuel between Malaysian Biodiesel Standards (MS 2008:2008), Colombian Biodiesel Standard (NTC 5444), European Standards (EN 14214) and US Standards (ASTM D6751).

In addition, the physical and chemical properties of palm biodiesel are required to follow on the basis of the recognized international standards of biodiesel and diesel. The biodiesel producers must meet these requirements to ensure the quality of the biodiesel, which is going to be the substitute of the conventional diesel fuel. Table 2 shows the comparison of physicochemical properties of the palm biodiesel which is produced in Malaysia and Colombia with respect to diesel fuel. The basic properties of palm biodiesel include density, kinematic viscosity, cloud point, pour point, flash point, higher heating value, oxidation stability and cetane number. It can be seen that biodiesel produced from palm oil has excellent properties, and it is much more comparable with the diesel fuel in terms of some properties. For example, it has higher cetane number than the diesel fuel, which improves the engine performances and reduces exhaust emissions [44]. Other than that, it also has comparable properties of density, viscosity and energy content with respect to the diesel fuel.

\section{Techno-economic Cost of Palm Oil Biodiesel Production}

The life cycle analysis can be defined as an economic model for pricing equipment and processes over the life span of a 


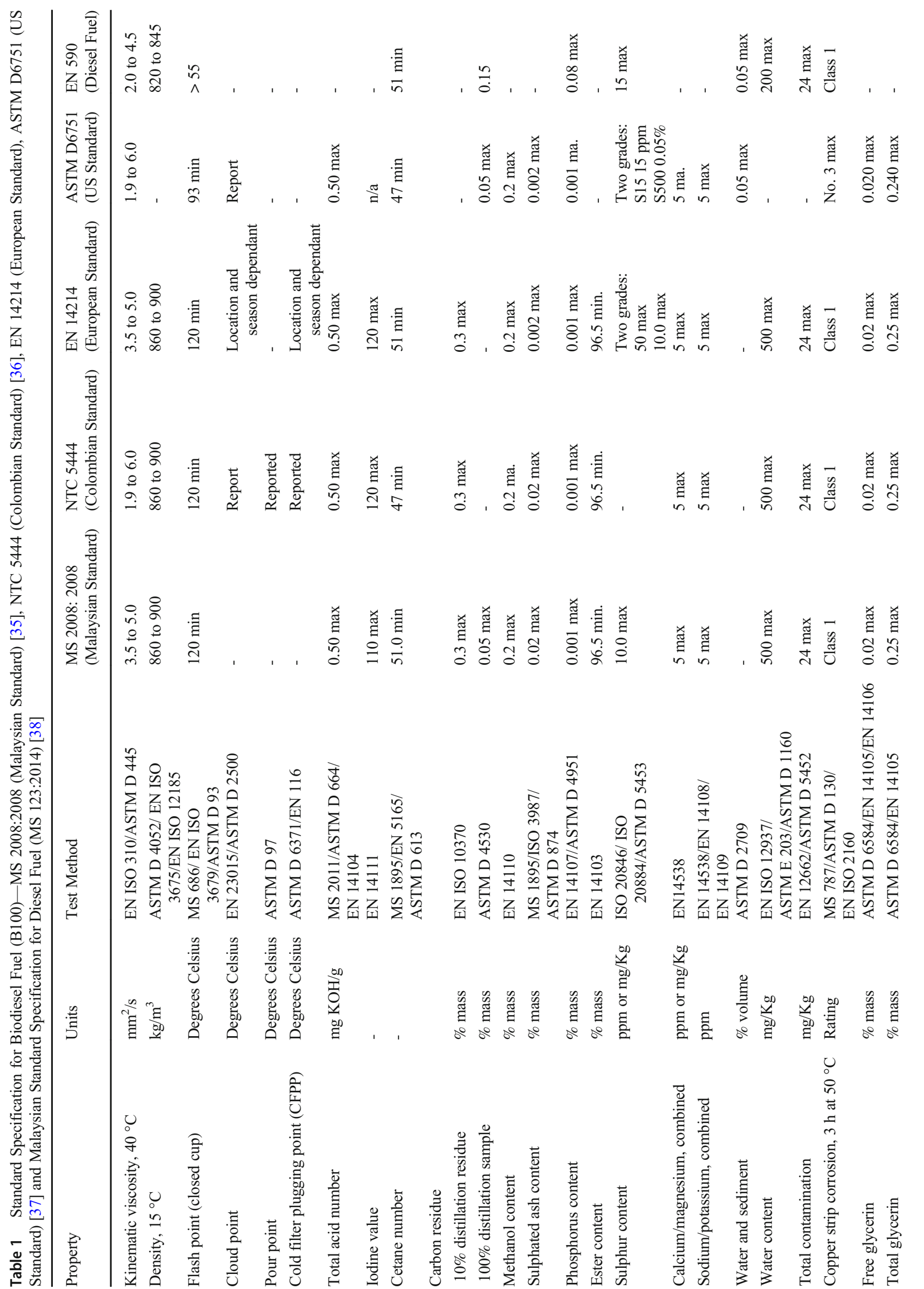




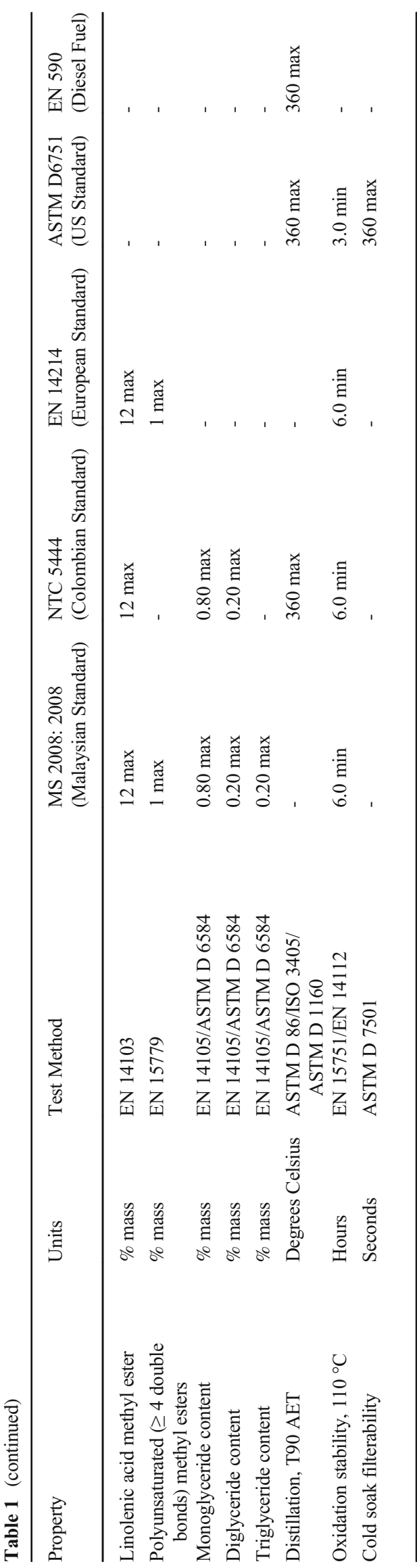

production plant. It involves installation cost, operating costs, maintenance costs, feedstock cost, by-product credit and salvage value at the end of the project lifetime. In biodiesel production, life cycle analysis is important to quantify the amount of energy and raw materials consumed, as well as emissions released at each of the production stages. The life cycle analysis for the biodiesel production process can be divided into three phases, which include agricultural, production and consumption phases as shown in Fig. 4.

The life cycle cost of the palm oil production can be derived as follows:

$$
\begin{aligned}
L C C= & \text { Capital Cost }+ \text { Operating Cost } \\
& + \text { Maintenance Cost } \\
& + \text { Feedstock Cost-Salvage Value-By product credit }
\end{aligned}
$$

The details of the LCC for palm oil production costs are tabulated in Table 3.

Ong, $\mathrm{HC}$ et al. [45] studied the life cycle cost for 50 ktons of palm biodiesel production plant in Malaysia with an operating period of 20 years which is $\$ 665$ million, yielding a payback period of 3.52 years. The study shows that feedstock cost has the largest share which accounts for $79 \%$ of the total production cost. Sensitivity analysis results also indicated that the variation in feedstock price will significantly affect the life cycle cost for biodiesel production. An increase of $\$ 0.10 / \mathrm{kg}$ of crude palm oil will cause a $\$ 0.05 / \mathrm{L}$ rise in the production cost. The study also found that the price of biodiesel is compatible with diesel when fiscal incentive and subsidy policy are implemented. Besides that, Acevedo JC et al. [46] also reported the operating costs of palm biodiesel pilot plant in Colombia with a capacity of $20,000 \mathrm{~L} /$ day. The detailed breakdown of biodiesel production costs shows that the feedstock required is the highest cost needed with $72.6 \%$ of the total production cost.

\section{Biofuel Policy and Programme}

\section{Malaysia}

The development and implementation of alternative, cheaper, sustainable and locally available fuel supply is a priority to be focused on. The Malaysian government has invested in research and development of biodiesel technology since 1982, which has been conducted by the Malaysian Palm Oil Berhad (MPOB) (formerly known as PORIM), SIRIM Berhad and many local universities. The government has initiated a range of policies to improve biofuel industry in the country. The National Biofuel Policy of Malaysia was launched in 2006 to discover green renewable energy sources, strengthen the palm oil industry, improve socio-economy safety net as well as reduce dependency on fossil fuels [47]. The Malaysian 


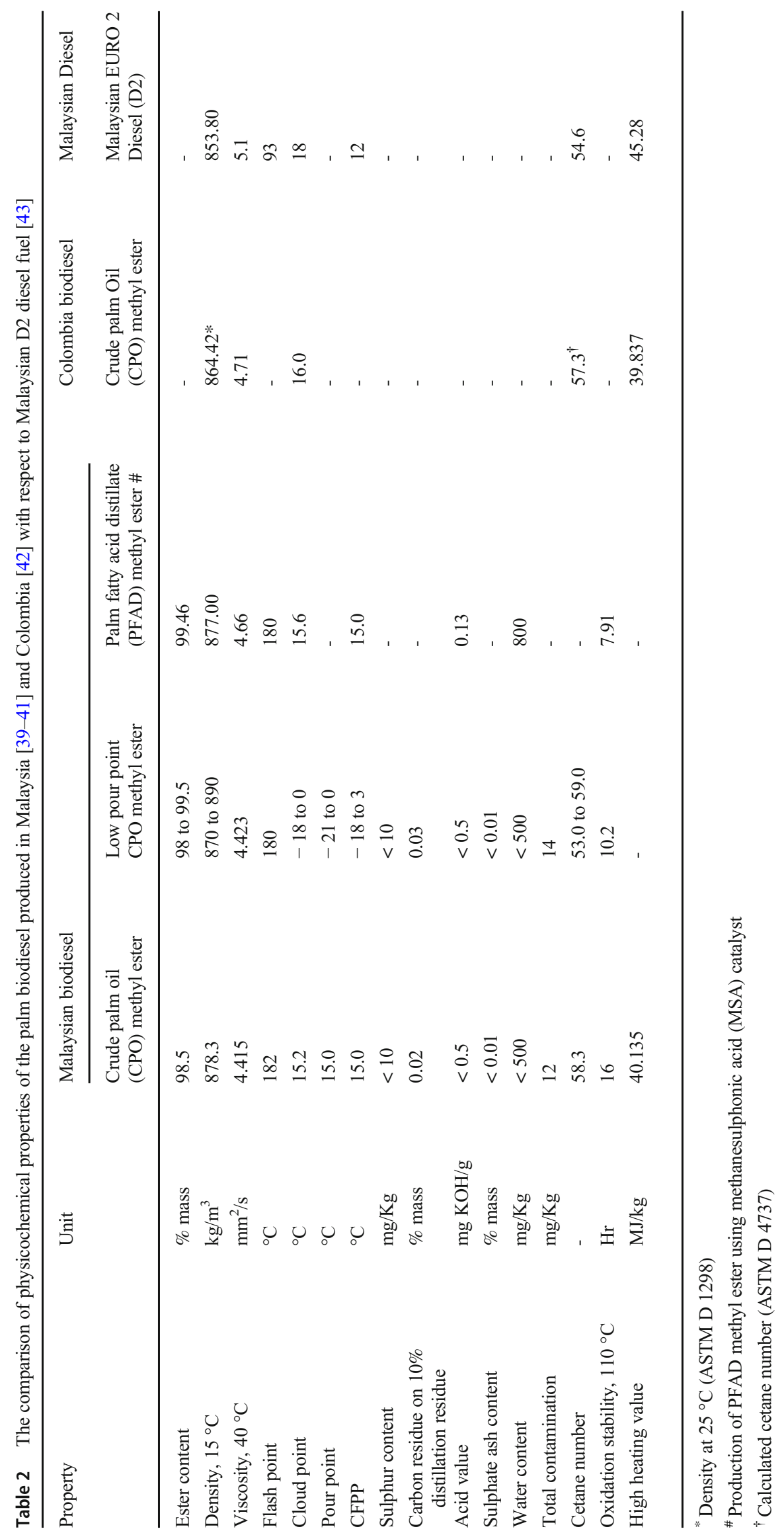


Fig. 4 Life cycle analysis diagram for biodiesel production [45]

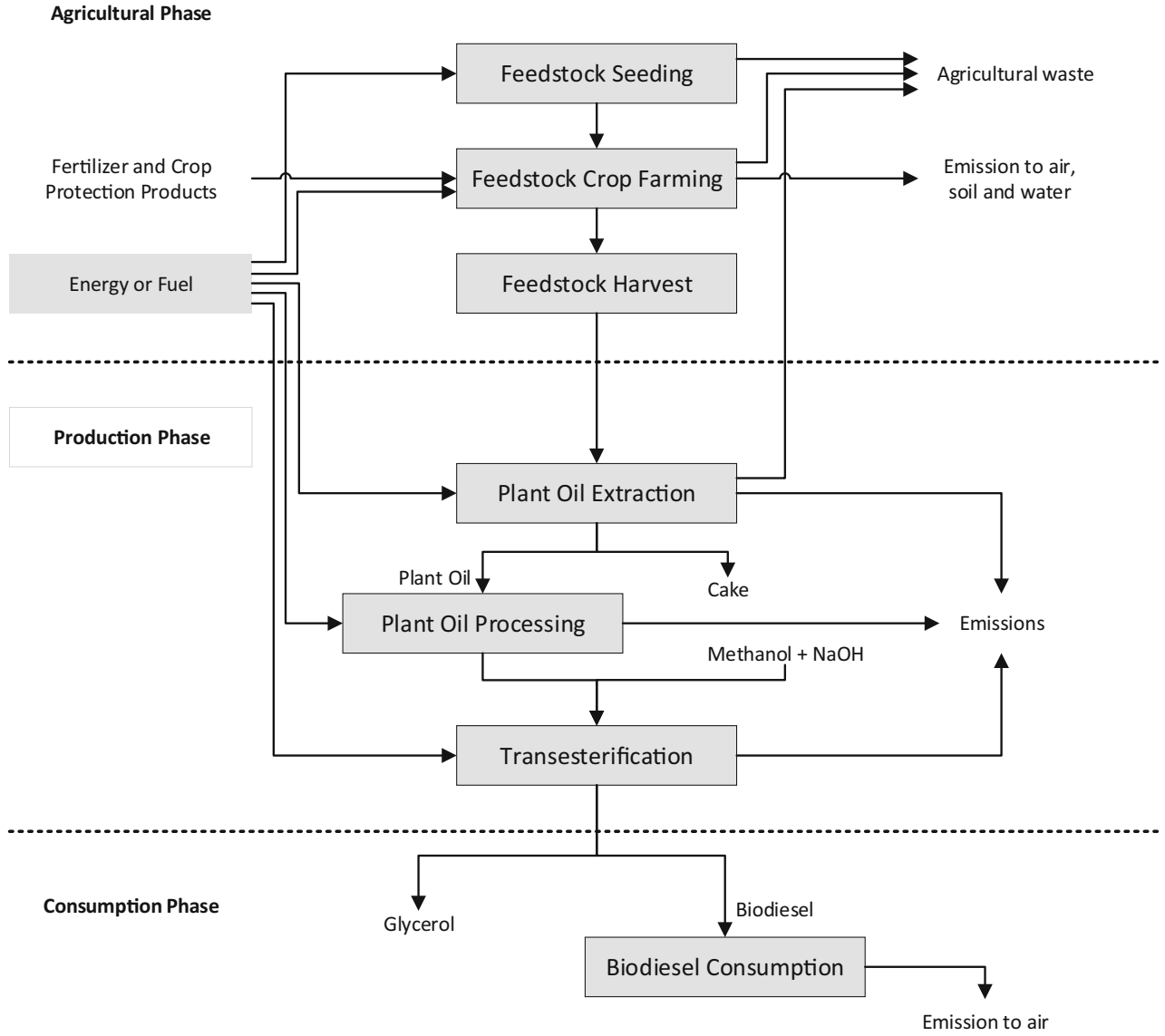

policy of biofuel presents a comprehensive framework in line with the objectives of the United Nations Framework Convention on Climate Change (UNFCCC) as a participating country, and also European Union (EU) [48]. Therefore, the utilization of biodiesel in Malaysia will be able to improve energy security, reduce greenhouse gas emissions and raise rural incomes and employments.
Figure 5 shows the strategic dimensions and implementation of the NBP in Malaysia. Malaysia's NBP consists of five strategic thrusts, which includes biofuels for transport, industry, technologies, export and a cleaner environment. The implemented policy was planned into three terms, i.e. short, medium and long terms, to emphasize Malaysia's contribution to the world's renewable energy objective. Since land and sea
Table 3 The details of the LCC of the palm oil biodiesel production

\begin{tabular}{ll}
\hline Type of cost & Details \\
\hline Capital cost & - Capital cost mainly depends on production capacity \\
& - The cost includes the required land area, building construction, \\
equipment and instrumentation required for the plant & - The operating cost includes utilities, lab services, factory expenses, \\
transportation cost, supervision, administration, labour cost, all \\
other materials and energy flows except the feedstocks \\
Operating cost & Also includes the cost associated with wastewater treatment and \\
& sludge waste processing \\
- The cost associated with maintaining and servicing the plant & The cost of the feedstocks is the main component of the overall costs \\
Maintenance cost & - The remaining value of the components and assets of the plant \\
Salvage value & at the end of the project lifetime \\
By-product credit & The revenues earned from all the products other than the primary \\
product; e.g. glycerol is a useful by-product generated & during biodiesel reaction
\end{tabular}




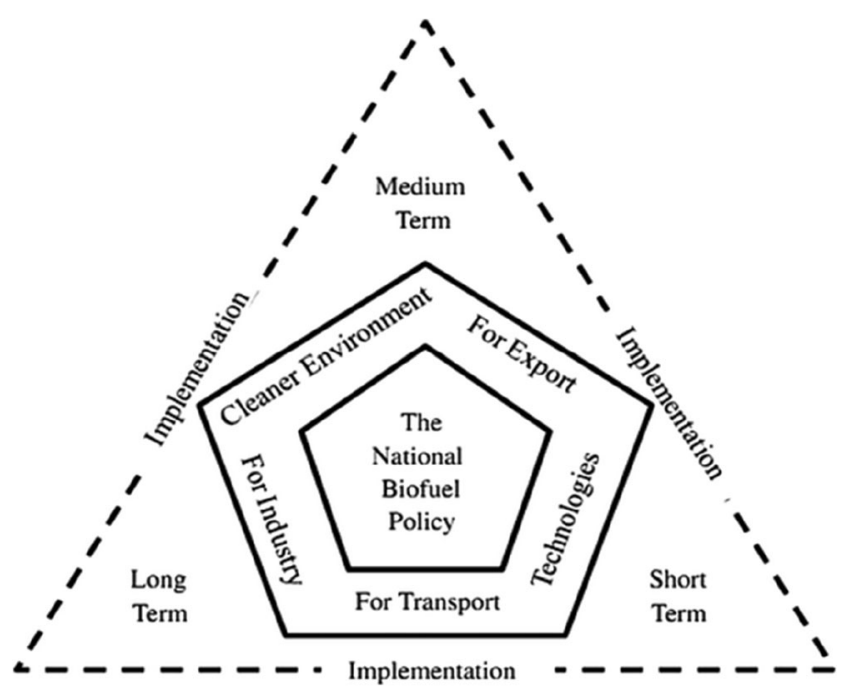

Fig. 5 Strategic dimensions and implementation of the National Biofuel Policy in Malaysia [49]

transportations are the largest consumers of diesel in the country, the policy was affected in 2009 for transportation sector as it is highly subsidized. The utilization of biodiesel blend in diesel-powered engines was initially introduced for governmental agencies such as Kuala Lumpur City Hall (DBKL) and Malaysia Armed Forces (ATM), followed by the Royal Malaysia Police (PDRM) and Ministry of Health [48].

The $\mathrm{B} 5$ biodiesel blend was officially implemented in 2011 in the state of Negeri Sembilan, Selangor, Kuala Lumpur, Putrajaya and Malacca, followed by Johor in 2013. Full nation implementation in both West and East Malaysia has been achieved at the end of 2014. The B7 biodiesel blend was then fully implemented throughout the country to replace the former B5 blend in 2015. To date, Malaysia has rolled out B10 mandate in February 2019 for the transportation sector while introducing B7 mandate for industrial sector in July 2019. This implementation will increase the local consumption of the palm oil harvested as well as reduce surplus in the global market. The biodiesel suppliers are also exempted from paying the $10 \%$ sales and services tax (SST) for their sales to the oil companies, i.e. Petronas, Petron, Shell and BH Petrol.

The regulation of Malaysian Biofuel Industry Act 2007 was enacted by the Malaysian Parliament in 2008. This act was introduced in line with the National Biofuel Policy 2006 to provide a mandatory to implement biodiesel blend mandate for palm oil biodiesel with petroleum diesel (B5 blend) and regulatory regime for licensing of blending, storage, transportation and export activities related to biofuel industry. This enforcement helps biodiesel producers, refiners or suppliers to reduce administrative barriers by streamlining the licencing process.

Besides that, the Malaysian government launched the Eleventh Malaysia Plan (2016-2020) to support the palm oil industries towards realizing Vision 2020 to achieve full development in Malaysia [50]. The government aims to increase palm biodiesel blending requirements up to $15 \%$ (B15 mandate) in automotive fuel and implementing the EURO 5 emission standards by 2020 for the road sector. In order to promote efficient utilization of energy in Malaysia, the government also launched the National Green Technology Policy (GTMP) on 24 July 2009, which earmarked green growth as one of the six game changers altering the trajectory of the nation's growth. The policy facilitates the mainstreaming of green technology into the planned developments of Malaysia while consisting of four pillars, i.e. energy, environment, economy and social, and aims to accelerate the national economy and promote sustainable development. Malaysia is really committed to further reduce greenhouse gas emissions intensity by $1083 \mathrm{KtCO}_{2}$ eq in the year 2020 relative to the emissions intensity in 2013, as part of its commitment under the Kyoto Protocol and the Paris Agreement [51].

\section{Colombia}

Colombia has implemented a solid biofuel policy designed to produce a regulatory framework and create instruments and financial conditions to promote sustainable production of biofuels. The Colombian biofuel policy aims to support additional revenue stream for the sugarcane and palm oil industries, diversify sources of the energy by reducing its dependency on fossil fuels and introduce a clean and environmentally friendly fuel to reduce GHG emissions. Biofuel initiative was launched in Colombia with the establishment of Law 693 of 2001 for ethanol and Law 939 of 2004 for biodiesel. The first implementation of palm biodiesel in Colombia was begun in 2007, with an initial mandatory blend of $2 \%$ (B2) in some regions of the country. However, the B2 mandate is still being implemented in three border departments due to some problems with cross-border smuggling issue. On February 2017, the biodiesel blend mandate has increased from B9 to B10 in Bogota as well as the central and eastern region, by considering Colombia's environment commitments and to increase biodiesel plants production capacity. The biodiesel blending mandate in Colombia is occasionally being changed across the country. This is because the Colombian government changes their mandate to accommodate domestic industry rather than satisfying blending mandate goals. In March 2018, the Colombian government has raised the mandated biofuels' blend limit in gasoline and diesel, in a bid to tackle rising metropolitan cities pollution, contribute to Colombia's climate change commitments under the 2015 Paris Climate Conference (COP21), and resolve oversupply issue that threaten to disrupt biodiesel production [52].

The Ministry of Mines and Energy (MME) is responsible to regulate Colombia's biofuel policy. There are several comprehensive frameworks issued by the MME to control and regulate biodiesel quality standards, blending mandates as 
well as biodiesel market prices. The government passed a 2002 tax reform by eliminating value added tax (VAT) for biofuels and exempted the biofuels from the global tax. Moreover, the ethanol blended with gasoline is exempted from local surcharge tax, but the tax does not impose for biodiesel fuel. The most recent tax reform which known as green tax or carbon tax implemented in 2016 was imposed on fossil fuels (gasoline and diesel) but exempted for biofuels. Table 4 below shows the current biofuel and fossil fuel tax rates in Colombia.

Values are in Colombian pesos (COP). Exchanged rate used USD 1 = COP 3210.90

In 2011, a Sustainability Guide in Biomass Production and Processing in the Biofuel Chain (also known as GTC 213) was introduced in Colombia to promote the sustainability principles, criteria and recommendations for biofuels production.

\section{Discussion}

\section{Sustainability of Palm Cultivation and Biodiesel Fuel}

Sustainability is very crucial in biofuel industry. Recently, the European Parliament (EP) has been reported to be in the process of banning the utilization of palm oil for biofuel in 2020, while Britain and Iceland will stop to use this commodity in their retail markets. After receiving protest from the Council of Palm Oil Producing Countries (CPOPC), the EP agreed to phase out the palm biodiesel starting from 2020 to 2030 [21]. The palm has been claimed as unsustainable crop by palm oil competitors. They concern that the deforestation of millionyear-old tropical forest for the utilization of palm cultivation will lead to the extinction of wildlife species such as orangutan, Sumatran tiger, and elephant as well as increase GHG emissions.

As one of the world's biggest palm oil producers and exporters, Malaysia is committed to play a key role to ensure that the palm commodity remains sustainable and competitive fuel replacement for the global markets. Palm oil is a viable option to reduce the country's dependency on fossil fuels and it brings much benefits to the energy and transportation activities. It is an important fact that only $10 \%$ of palm oil production in Malaysia currently ends up towards non-food applications and the remaining are applied into food applications. Therefore, biofuel industry cannot be held solely responsible for the deforestation. On top of that, the Malaysian government committed to preserve half of Malaysia's total land areas for its forest to limit the expansion of the palm oil plantations in the country to 6.5 million hectares as a step towards ensuring the sustainability of the palm oil industry [53]. In fact, the expansion of palm oil plantation in Malaysia does not cause deforestation as most of the new lands are replacing other agricultural crops area such as rubber, coconut and cocoa which have lower market value. Besides that, the Malaysian government also took measures to prohibit palm cultivation on peat soils and permanent forest reserves across the country.

Moreover, the production size and quality of palm-based energy products in Malaysia is continuously improving as the country is equipped with the technology capabilities and market size along with support from various agencies such as the MPOB, SIRIM Berhad as well as Malaysia Automotive Robotics and IoT Institute [54]. In fact, Malaysian palm oil meets the strictest sustainability standards and was certified as sustainable under the Renewable Energy Directive (RED) by leading European sustainability schemes, regulated by the EU Commission.

Table 4 Colombian fuel taxes (Source: The data is obtained from USDA Gain Report CO1811 [26], which is sourced from Fuel Information System (SICOM), MME)

\begin{tabular}{|c|c|c|c|c|}
\hline Type of taxes & Tariff for biofuels & Tariff for gasoline & Tariff for diesel & Regulations \\
\hline Global tax & - Exempted & $\begin{array}{l}\cdot \text { Regular gasoline }- \text { COP } \\
510.04 \text { per gallon (USD 0.16) } \\
\text { - Premium gasoline }-\$ 964.04 \\
\text { per gallon (USD } 0.30)\end{array}$ & $\begin{array}{l}-\$ 488.18 \text { per gallon } \\
\quad \text { (USD 0.15) }\end{array}$ & $\begin{array}{l}\cdot \text { Law } 1607 \text { of } 2012 \text {-Article } \\
\text { 167, 168, } 173 \\
\text { - Law } 1819 \text { of } 2016 \text {-Article } \\
\quad 218,219,220\end{array}$ \\
\hline $\begin{array}{l}\text { Value added } \\
\operatorname{tax}(\text { VAT) }\end{array}$ & - Exempted & $\cdot 19 \%$ & $\cdot 19 \%$ & $\begin{array}{l}\text { - Law } 1607 \text { of } 2012-\text { Article } \\
\quad 167,168,173 \\
\text { - Estatuto Tributario } \\
\quad \text { (biofuels exempt)-Article } 477\end{array}$ \\
\hline Local surcharge tax & $\begin{array}{l}\text { - Exempted on } \\
\text { ethanol blended } \\
\text { with gasoline } \\
\text { - No tax relief for } \\
\text { biodiesel }\end{array}$ & $\begin{array}{l}\text { 25\% of the reference price. } \\
\text { Reference price for June } \\
\text { 2018: COP } 4751.05 \text { per } \\
\text { gallon (USD 1.48) }\end{array}$ & $\begin{array}{l}\text { - } 6 \% \text { of the reference price. } \\
\text { Reference price for June } \\
\text { 2018: COP } 4667.96 \\
\text { per gallon } \\
\text { (USD 1.45) }\end{array}$ & $\begin{array}{l}\text { - Law } 488 \text { of } 1998 \text {-Article } 117 \text { to } 121 \\
\text { - MME's resolution } 40575 \text { of } 2018\end{array}$ \\
\hline $\begin{array}{l}\text { Green tax or } \\
\text { carbon national tax }\end{array}$ & • Exempted & $\begin{array}{l}\cdot \text { COP } 135 \text { per gallon } \\
\text { (USD } 0.042 \text { ) }\end{array}$ & $\begin{array}{l}\cdot \text { COP } 152 \text { per gallon } \\
\text { (USD } 0.047 \text { ) }\end{array}$ & $\begin{array}{l}\text { - Decree } 926 \text { of } 2017 \\
\text { - Law } 1819 \text { of } 2016 \text {-Article 221, } \\
\quad 222,223\end{array}$ \\
\hline
\end{tabular}


Colombia is also standing firm on its position alongside with Malaysia and Indonesia to urge EU to not restrict the utilization of palm biodiesel within Europe. It is an important fact that $65 \%$ of the total palm oil plantation area in Malaysia are smallholder plantations which are usually managed by farmers and the rest are ruled by companies [55]. These palm crops are their primary source of income especially for the smallholder farmers; thus, it will only bring negative consequences to their quality of life if the EU ban is implemented. In terms of land usage, the Colombian palm oil is produced responsibly and sustainably on degraded lands and plains, where the lands were formerly cleared for cattle ranching, but not on their primary forest. The environmental impact of palm oil in Colombia is relatively low, although it is not completely deforestation free.

Additionally, a lot of local and international standards and policies have been implemented to tackle these issues and to have more sustainable development of palm oil industry. Relevant sustainable policies and/or conventions including the global Roundtable on Sustainable Palm Oil (RSPO) certification, Malaysian Sustainable Palm Oil (MSPO) scheme, European Union Renewable Energy Directives (EU-RED) 1 \& 2 and various zero-deforestation commitments. Besides that, the advancement in genetic modification technology, tissue culture propagation, marker-assisted breeding and marker-assisted selection have revolutionized the biotechnology applications to produce higher yield palm oil cultivations, thus meeting the energy growing demand and also ensuring the sustainable food supply [56]. The successful biotechnology provides a clear way towards sustainability of the biofuel industry. Furthermore, the crop growth simulation model also has been developed as an excellent assessment for the longterm different intercropping systems, thus giving more accurate information to support smallholder decision-making. In Colombia, a mobile app is being used by the producers as digital self-assessment tool to assess the sustainability level of their farm area [57].

\section{Impacts of Oil Palm Industry and Biodiesel Policy Towards Malaysian and Colombian Transportation System}

Palm oil biodiesel has always been the founding base of biodiesel policy in Malaysia and Colombia. The policy brings a lot of advantages to Malaysian and Colombian transportation systems in terms of environmental, technology, economy as well as social aspect. Since biodiesel is derived from renewable source such as palm oil as the replacement for fossil diesel, it can reduce the dependency on fossil fuels and eventually tackle on the issues of the pollution produced by them. The crops are more suitable for current world energy security, satisfying the world transportation needs. It is notably stated that oil palm is a highly efficient vegetable oil in comparison with other bearing crops; thus, it requires less plantation area, only 0.26 hectare to produce 1 ton of palm oil compared with 2.2, 2.0 and 1.5 hectares for soya bean, sunflower and rapeseed, respectively. At the same time, palm biodiesel also contributes to environmental stability where it considerably leads to less engine exhaust emissions in comparison with neat diesel. Several researchers have proven that palm oil biodiesel is a clean fuel because it will not increase the amount of carbon dioxide, carbon monoxide and hydrocarbon emissions during combustion [44, 58, 59]. Besides that, palm biodiesel is also biodegradable; thus, it is easier and safer to be utilized.

In addition, palm oil biodiesel mandate in transportation sector brings advantages in terms of technology development in Malaysia and Colombia. The countries are equipped with advanced technologies, facilities and expertise in this particular field to play a key role in ensuring that the palm oil biodiesel can bring much more benefits to global market especially for transportation and energy ecosystem. The researches done by MPOB and other experts from local universities resulted in the development of several technological processes to convert crude palm oil and palm kernel oil into methyl ester for the application of biodiesel. Palm methyl ester or palm biodiesel is often used as a fuel blend with petroleum diesel inside many diesel vehicles without engine modification.

The competitiveness of the oil palm industry and successful implementation of the biodiesel policy would benefit to the Malaysian and Colombian economy as well. In Malaysia, the oil palm industry attains a significant achievement in palm oil production and exports, which contributes 5 to $7 \%$ of Malaysia's gross domestic product (GDP), exchange earnings as well as creation of job opportunities [60]. In fact, Malaysia's export revenue palm oil alone averages at MYR 64.24 billion per annum for the last 5 years. Malaysia also expanded its export markets to more than 200 markets worldwide, including India sub-continent, West Asia and Africa to cater the ever-growing demand of consumers. Meanwhile, in Colombia, oil palm sector has contributed $0.22 \%$ to the country's GDP [61]. Colombia's palm oil industry is expected to move forward with plans to increase palm oil production, targeting six times increment in 2020.

Furthermore, promoting oil palm production and biofuel policy for transportation sector is positive for smallholder and small-scale oil palm growers who represent approximately $40 \%$ of the total global palm oil production. In Malaysia, as of April 2017, the number of people directly employed into the oil palm industry registered at 440,262 (exclusive of 280,977 independent smallholders). The oil palm cultivation and biodiesel blending mandate directly and indirectly gives socio-economic benefits to the oil palm growers to increase their living standard, which provides primary income source from steady demand, thus allowing thousands of the oil palm growers to invest in improving their cropland, enhancing environmental conditions and providing a good education for 
their children [57]. Meanwhile, Colombian oil palm industry engages more than $80 \%$ of the smallholders and small-scale growers, literally providing important source of income for them. The oil palm industry also gives opportunity to the smallholder and farmers to prepare for retirement in their future.

\section{Potential International Collaboration Between Malaysia and Colombia in Biofuel Industry}

Malaysia and Colombia are looking forward to ramp up palm biodiesel consumption in ensuring their mandates get implemented as per planned. Malaysia's MPI plans to double its current biodiesel programme to B20 in transportation sector by 2020 and B30 by 2025. Meanwhile, Colombia's MME has drafted a resolution to increase biodiesel mandate to B12 by 2019. Prior to that, biodiesel implementation roadmap, an international collaboration as shown in Fig. 6, will be a good initiative for both countries to improve their existing policies, strategies and blueprints relating to the biodiesel industry development.
The difference between Malaysian and Colombian palm oil policy is that the Malaysian policy is initiated for domestic use in transportation and related sectors and currently is focusing in becoming the world's largest palm oil exporter. Meanwhile, the Colombian palm industry policy is entirely focused on local consumption to meet the biodiesel blend mandate and not for the trades. In fact, the production of palm biodiesel in Malaysia is at 907 million litres in 2017, and it was expected to increase to 1.22 and 1.56 billion litres in 2018 and 2019, respectively [21]. The production of palm biodiesel in Colombia registered is at 393 million litres in 2017, and it is projected to reach 480 million in 2018. In addition, Malaysia has exported 267 million litres in 2017, while Colombia neither imports or exports palm biodiesel. Through this international cooperation, Malaysia can help in improving Colombia palm oil biodiesel production yield and quality at a lower cost. There are several reasons for the higher production cost in Colombia such as poor soil condition in certain plantation area, bud rot disease, low degree of mechanisation and high labour charge. In fact, as the world's largest palm oil exporter, Malaysia is able to lend a helping hand to promote Colombia

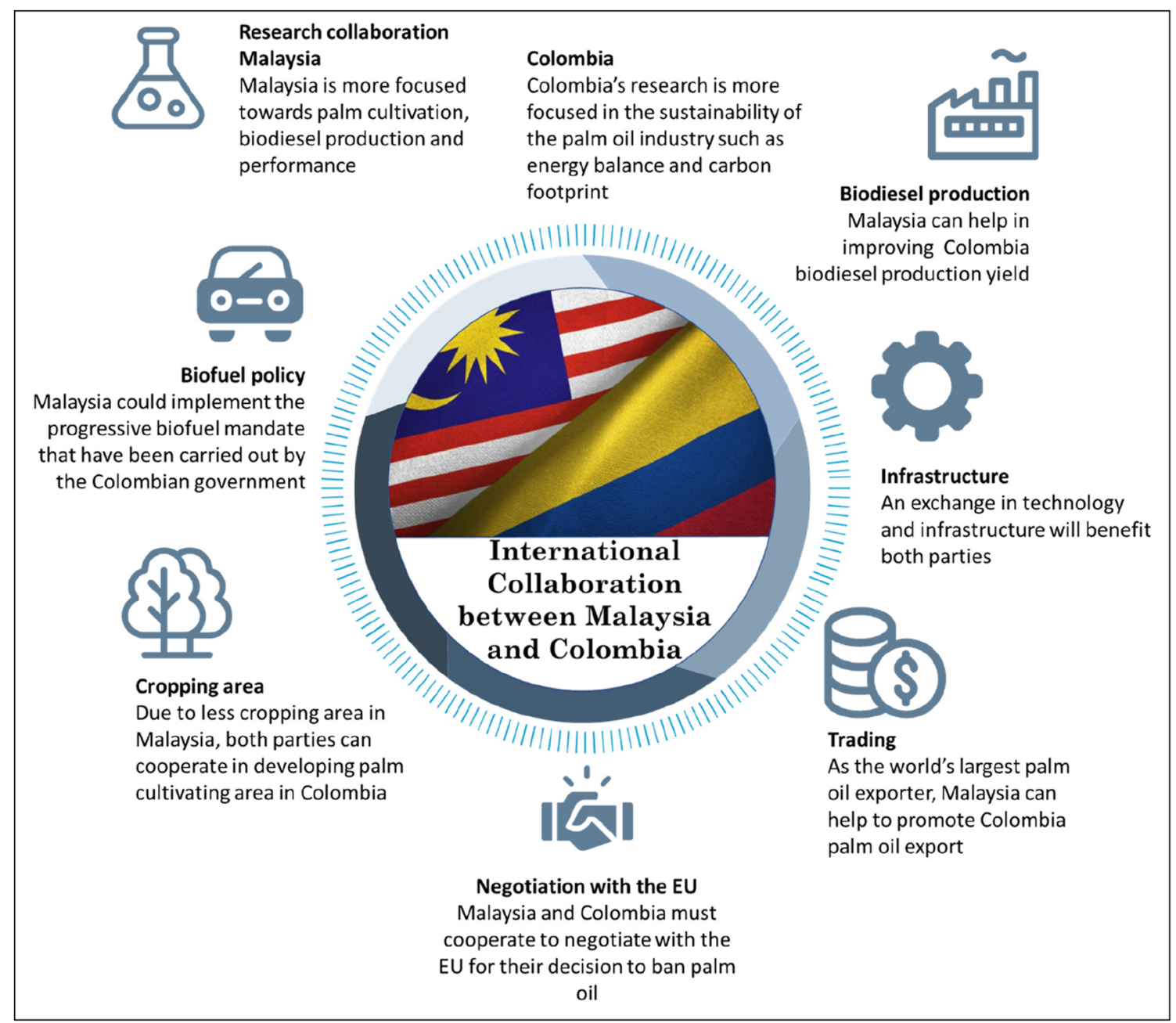

Fig. 6 Potential international collaboration between Malaysia and Colombia 
palm oil for exportation. This situation also promotes Malaysian palm oil players to do joint ventures with the existing biodiesel companies in Colombia.

Besides that, collaborative research between Malaysia and Colombia may result in more sustainable development of biodiesel industry to meet global quest, thus providing greater benefit to the industry as a whole. There are several reasons for the higher production cost in Colombia such as poor soil condition in certain plantation area, bud rot disease, low degree of mechanisation and high labour charge. For example, Malaysia has been able to produce high-quality winter-grade palm biodiesel consistently at an optimised cost. This biodiesel grade is suitable to be used in non-tropical region as they experience winter season. Malaysia has also successfully introduced a hybrid oil palm tree between the deli dura and pisifera species, known as tenera which is the most efficient oil-bearing crop in the world. The tenera species requires 0.26 hectares of land to produce one tonne of the oil. Meanwhile, the researches in Colombia are more focused on the sustainability of the palm biodiesel production in terms of socioeconomic impact, carbon footprint, agribusiness and energy balance. Since both countries complement each other, a crossdisciplinary collaborative research is strongly required to improve the quality and sustainability of the palm oil production in a manner by following RSPO standards and adopting good agricultural practices.

The fact that Malaysia has limited amount of lands to further expand their palm cultivation area, hence, they have to convert secondary forest and other existing crops area such as rubber, cocoa and coconut which are less competitive compared with oil palm. However, Colombia has ample land availability with a potential area of 3.5 million hectares for palm cultivating area. Therefore, Malaysian palm oil companies have to put into consideration to invest for global plantation and refining capacity in Colombia which has similar soil and climate conditions.

Moreover, technology cooperation between Malaysia and Colombia is important towards sustainability of palm oil biodiesel in transportation sector. An exchange in technology and infrastructures will benefit both Malaysia and Colombia. Through years of extensive researches, Malaysia can provide relevance technologies, expertise and experience in terms of biotechnology, biodiesel processing as well as fuel blending. Malaysia has successfully decoded palm oil genome to further increase palm oil yield. Apart from that, Malaysia is also now recognized as one of the most cost-effective biodiesel production processes, thus having higher demands from many countries. By encouraging technological exchange, these technologies can be utilized to aid the production process of biodiesel in Colombia. Further expansion of palm cultivating area will affect the sustainability of our nature. In this context, advanced technology and expertise are needed to increase the crops yield per cultivation area. The expertise of Colombia in precision agricultural techniques, plant agronomy as well as biotechnology also can help Malaysia to further optimized production rate within land availability.

Another strength of Colombia is that the country has a fairly strong biofuel policy and programmes that promote sustainable energy and biofuels in transportation sector. Besides being a world bioethanol pioneer, Colombian biodiesel projects are gaining strength, thus giving greater impact to the society, economy and environment. Though Colombia does not focus on biodiesel export, its biodiesel policy is more focusing on domestic uses based on Colombian Law 939 of 2004. The Colombian full implementation of biodiesel blend in transportation began in 2007 and currently implement B9 B10 since 2017. Meanwhile, Malaysian full nation implementation of biodiesel blend officially took place in 2014 and currently implemented B10 on February 2019. As the largest biodiesel exporter, Malaysian government should take an aggressive approach to convince the automobile manufacturers to increase the utilization of palm biodiesel in transportation sector. The adoption of higher biodiesel blend policy is a solution to increase domestic consumption of palm oil, and at the same time, it acts as an alternative to heavy reliance on export of palm oil.

Furthermore, the oil palm industry in Malaysia and Colombia faces many challenges and negative perception especially from the palm oil competitors in western countries. They are claiming that the oil plantations are unsustainable which causes deforestation, thus leading to climate change and mass species extinction. Through this collaboration, Malaysia may work closely with Colombia to negotiate in a constructive manner in seeking dispute settlements on the EU's decision to phase out the utilization of palm biodiesel. In this regard, both countries are able to voice out their common concerns towards the issue to ensure that the palm commodity receives non-discriminatory treatment, thus allowing market access into the EU countries. Besides that, both countries may also work together in promoting palm oil to raise public awareness among consumers.

\section{Conclusion}

The implementation of palm oil biodiesel as an alternative fuel to the conventional petroleum hydrocarbon marks an important milestone in reducing the harmful emissions from the combustion of fossil fuels. However, the sustainability of the palm biodiesel industry is very crucial as the increase of palm biodiesel production can cause global imbalance to the food industries. Thus, several local and international sustainability standards and policies have been implemented to ensure the sustainable development of the industry which includes forest conservation, environmental management, biological control of pests and reduction of greenhouse gases. As major players 
of the palm oil business, Malaysia and Colombia can deal with their internal consumption of palm oil products (food, biodiesel, etc.) and are committed to ensuring that the palm commodity remains sustainable for the global markets through the implementation of various policies. Palm oil biodiesel has been the founding base of biodiesel policies for the transportation sector in both Malaysia and Colombia. The policies bring a lot of advantages to the countries' transportation systems in terms of environmental, technology, economy and social aspect. Both countries are equipped with advanced technologies, facilities and expertise in this particular field in ensuring that the palm oil biodiesel can bring many more benefits to the global market especially for transportation and energy ecosystem. Owing to that reason, international collaboration between these two nations would be a good initiative to improve their existing policies, strategies, and blueprints relating to the palm biodiesel industry development especially to their respective regions. The successful collaboration between Malaysia and Colombia can overcome the challenges when dealing with the global energy issue and consequently become a good role model for other countries.

Acknowledgement The authors would like to acknowledge with gratitude the financial support given by the University of Malaya under the Equitable Society Research Cluster (ESRC) research grant GC003D17SBS entitled 'Enhancement of Biofuel Production from Tropical Biodiversity Sources'.

\section{References}

1. IPCC (2001) Climate change 2001: The scientific basis. Cambridge University Press https://www.ipcc.ch/site/assets/uploads/2018/03/ WGI TAR full report.pdf. Accessed 30 June 2019

2. IPCC (2014) Climate change 2014: Mitigation of climate change. Cambridge University Press https://www.ipcc.ch/site/assets/ uploads/2018/02/ipcc_wg3_ar5_full.pdf. Accessed 10 July 2019

3. Mujtaba M, Cho HM, Masjuki H, Kalam M, Ong H, Gul M, Harith M, Yusoff M (2020) Critical review on sesame seed oil and its methyl ester on cold flow and oxidation stability. Energy Rep 6: 40-54. https://doi.org/10.1016/j.egyr.2019.11.160

4. Yusoff MNAM, Zulkifli NWM, Masjuki HH, Harith M, Syahir A, Khuong L, Zaharin MSM, Alabdulkarem A (2018) Comparative assessment of ethanol and isobutanol addition in gasoline on engine performance and exhaust emissions. J Clean Prod 190:483-495. https://doi.org/10.1016/j.jclepro.2018.04.183

5. Janssen R, Rutz DD (2011) Sustainability of biofuels in Latin America: risks and opportunities. Energy Policy 39(10):57175725. https://doi.org/10.1016/j.enpol.2011.01.047

6. Yusoff MNAM, Zulkifli NWM, Masum BM, Masjuki HH (2015) Feasibility of bioethanol and biobutanol as transportation fuel in spark-ignition engine: a review. RSC Adv 5(121):100184100211. https://doi.org/10.1039/C5RA12735A

7. Lopes ML, de Lima Paulillo SC, Godoy A, Cherubin RA, Lorenzi MS, Giometti FHC, Bernardino CD, de Amorim Neto HB, de Amorim HV (2016) Ethanol production in Brazil: a bridge between science and industry. Braz J Microbiol 47:64-76. https://doi.org/10. 1016/j.bjm.2016.10.003
8. Kalam M, Masjuki H (2002) Biodiesel from palm oil—an analysis of its properties and potential. Biomass Bioenergy 23(6):471-479. https://doi.org/10.1016/S0961-9534(02)00085-5

9. Liu X, He H, Wang Y, Zhu S, Piao X (2008) Transesterification of soybean oil to biodiesel using $\mathrm{CaO}$ as a solid base catalyst. Fuel 87(2):216-221. https://doi.org/10.1016/j.fuel.2007.04.013

10. Pimentel D, Patzek TW (2005) Ethanol production using corn, switchgrass, and wood; biodiesel production using soybean and sunflower. Nat Resour Res 14(1):65-76. https://doi.org/10.1007/ s11053-005-4679-8

11. Silitonga A, Ong HC, Mahlia T, Masjuki H, Chong W (2014) Biodiesel conversion from high FFA crude jatropha curcas, calophyllum inophyllum and ceiba pentandra oil. Energy Procedia 61:480-483. https://doi.org/10.1016/j.egypro.2014.11.1153

12. Ghadge SV, Raheman H (2005) Biodiesel production from mahua (Madhuca indica) oil having high free fatty acids. Biomass Bioenergy 28(6):601-605. https://doi.org/10.1016/j.biombioe. 2004.11.009

13. Nautiyal P, Subramanian K, Dastidar M (2014) Production and characterization of biodiesel from algae. Fuel Process Technol 120:79-88. https://doi.org/10.1016/j.fuproc.2013.12.003

14. Phan AN, Phan TM (2008) Biodiesel production from waste cooking oils. Fuel 87(17-18):3490-3496. https://doi.org/10.1016/ j.fuel.2008.07.008

15. Banković-Ilić IB, Stojković IJ, Stamenković OS, Veljkovic VB, Hung Y-T (2014) Waste animal fats as feedstocks for biodiesel production. Renew Sust Energ Rev 32:238-254. https://doi.org/ 10.1016/j.rser.2014.01.038

16. Lam MK, Tan KT, Lee KT, Mohamed AR (2009) Malaysian palm oil: surviving the food versus fuel dispute for a sustainable future. Renew Sust Energ Rev 13(6-7):1456-1464. https://doi.org/10. 1016/j.rser.2008.09.009

17. Murphy DJ (2014) The future of oil palm as a major global crop: opportunities and challenges. J Oil Palm Res 26(1):1-24 http://jopr. mpob.gov.my/the-future-of-oil-palm-as-a-major-global-cropopportunities-and-challenges/

18. EIA (2017) Country Analysis Brief: Malaysia. U.S. Energy Information Administration. http://www.ieee.es/Galerias/fichero/ OtrasPublicaciones/Internacional/2017/EIA_Malasya_26abr2017. pdf. Accessed 30 June 2019

19. Energy Commission Malaysia (2018) National Energy Balance 2016. Energy Commission Malaysia, Putrajaya

20. Ong H (2018) Potential study of diversified transportation energy mix - Malaysia. In: Toba M, Goto S, Ichikawa S, Chollacoop N, Anbumozhi V (eds) Study of renewable energy potential and its effective usage in East Asia Summit countries. Economic Research Institute for ASEAN and East Asia, Indonesia, pp 62-70

21. Wahab AG (2018) Malaysia Biofuels Annual 2018 - USDA GAIN Report MY8010. USDA Foreign Agricultural Services. https:// a p p s.fas.usda.gov/newgainapi/api/report/ downloadreportbyfilename?filename $=$ Biofuels $\% 20$ Annual Kuala\%20Lumpur_Malaysia_12-19-2018.pdf. Accessed $\overline{5}$ July 2019

22. EIA (2016) Country Analysis Brief: Colombia. U.S. Energy Information Administration. https://www.eia.gov/beta/ international/analysis_includes/countries_long/Colombia/ colombia.pdf. Accessed $\overline{1}$ July 2019

23. EIA (2019) Country analysis executive summary: Colombia. U.S. Energy Information Administration. https://www.eia.gov/beta/ international/analysis.php?iso=COL. Accessed 1 July 2019

24. Nieves M, Hernández A (2016) Colombia Energy Investment Report. Energy Chartered Secretariat, Brussels

25. EMIS (2017) Colombia Transportation Sector Report 2016/2017. https://www.emis.com/blog/colombia-transportation-sector20162017. Accessed 5 July 2019 
26. Lady AG, Michael C (2018) Colombia Biofuels Annual 2018 Colombia increases biofuel blend mandate to $10 \%$. USDA Foreign Agricultural Service. https://gain.fas.usda.gov/Recent\% 20GAIN\%20Publications/Biofuels\%20Annual_Bogota_ Colombia 7-6-2018.pdf. Accessed 5 July 2019

27. Sumathi S, Chai S, Mohamed A (2008) Utilization of oil palm as a source of renewable energy in Malaysia. Renew Sust Energ Rev 12(9):2404-2421. https://doi.org/10.1016/j.rser.2007.06.006

28. Crutchfield J (2007) Indonesia: palm oil production prospects continue to grow. United States Department of Agriculture - Foreign Agriculture Services. https://ipad.fas.usda.gov/highlights/2007/12/ indonesia_palmoil/. Accessed 10 July 2019

29. Syahir A, Zulkifli N, Masjuki H, Kalam M, Alabdulkarem A, Gulzar M, Khuong L, Harith M (2017) A review on bio-based lubricants and their applications. J Clean Prod 168:997-1016. https://doi.org/10.1016/j.jclepro.2017.09.106

30. Malaysian Palm Oil Board (2019) Overview of the Malaysian Oil Palm Industry 2018. Malaysian Palm Oil Board. http://palmoilis. mpob.gov.my/V4/overview-of-industry-2018/. Accessed 9 July 2019

31. Malaysian Palm Oil Board (2010) Overview of the Malaysian oil palm industry 2010. Malaysian Palm Oil Board. http://palmoilis. mpob.gov.my/V4/overview-of-industry-2010/. Accessed 5 July 2019

32. OECD \& FAO (2019) OECD-FAO Agricultural Outlook 20192028. OECD Publishing, Paris. https://doi.org/10.1787/agr_ outlook-2019-en

33. Malaysian Palm Oil Board (2018) Export of palm oil by destination. Malaysian Palm Oil Board. http://bepi.mpob.gov.my/index. php/en/statistics/export/192-export-2018/867-export-of-palm-oilto-major-destinations-2018.html. Accessed 10 July 2019

34. Chin M (2011) Biofuels in Malaysia: an analysis of the legal and institutional framework. Working Paper 64. Center for International Forestry Research, Bogor, Indonesia

35. Choo YM, Harrison LLN, Yung CL (n.d.) Biodiesel standard development $\&$ impacts of palm biodiesel on engines and emissions. Malaysian Palm Oil Berhad, Selangor

36. Fontalvo Gómez M, Vecino Pérez R, Barrios Sarmiento A (2014) African palm oil elaeis guineensis: alternative energy resource to biodiesel production in Colombia and its environmental impact. Prospectiva 12(1):90-98. https://doi.org/10.15665/rp.v12i1.155

37. Jääskeläinen H (2009) Biodiesel standards \& properties. Ecopoint Inc. https://www.dieselnet.com/tech/fuel_biodiesel_std.php. Accessed 26 June 2019

38. Chevron Fuels Technical Service (2007) Diesel Fuels Technical Review. Chevron Corporation, San Ramon

39. May CY, Liang YC, Foon CS, Ngan MA, Hook CC, Basiron Y (2005) Key fuel properties of palm oil alkyl esters. Fuel 84(12-13): 1717-1720. https://doi.org/10.1016/j.fuel.2005.02.010

40. Wafti N, Lau H, Choo Y (2015) Production technology of biodiesel from palm fatty acid distillate using mild acid catalyst. J Oil Palm Res 27(4):352-359:http://jopr.mpob.gov.my/productiontechnology-of-biodiesel-from-palm-fatty-acid-distillate-usingmild-acid-catalyst

41. Choo YM, Ma AN, Yusof B (1993) Palm oil methyl esters as fuel: palm diesel. Palm Oil Research Institute of Malaysia. Ministry of Primary Industries, Malaysia http://palmoilis.mpob.gov.my/ images/PORIM\%20IS/0017/PORIM\%20IS\%200017.pdf. Accessed 10 July 2019

42. Benjumea P, Agudelo J, Agudelo A (2008) Basic properties of palm oil biodiesel-diesel blends. Fuel 87(10-11):2069-2075. https://doi.org/10.1016/j.fuel.2007.11.004
43. Sugeng DA, Zahari MFHM, Ithnin AM, Yahya WJ (2017) Diesel engine fuel consumption and emission analysis using steam generated non-surfactant water-in-diesel emulsion fuel. In: IOP Conf Ser Mater Sci Eng, vol 1. IOP Publishing, p 012036. https://doi.org/10. 1088/1757-899X/257/1/012036

44. Mofijur M, Masjuki HH, Kalam M, Atabani AE, Fattah IR, Mobarak H (2014) Comparative evaluation of performance and emission characteristics of Moringa oleifera and Palm oil based biodiesel in a diesel engine. Ind Crops Prod 53:78-84. https://doi. org/10.1016/j.indcrop.2013.12.011

45. Ong H, Mahlia T, Masjuki H, Honnery D (2012) Life cycle cost and sensitivity analysis of palm biodiesel production. Fuel 98:131-139. https://doi.org/10.1016/j.fuel.2012.03.031

46. Acevedo JC, Hernández JA, Valdés CF, Khanal SK (2015) Analysis of operating costs for producing biodiesel from palm oil at pilot-scale in Colombia. Bioresour Technol 188:117-123. https://doi.org/10.1016/j.biortech.2015.01.071

47. Ministry of Plantation Industries and Commodities Malaysia (2006) The national biofuel policy. MPIC, Kuala Lumpur

48. Abdullah AZ, Salamatinia B, Mootabadi H, Bhatia S (2009) Current status and policies on biodiesel industry in Malaysia as the world's leading producer of palm oil. Energy Policy 37(12): 5440-5448. https://doi.org/10.1016/j.enpol.2009.08.012

49. Rahyla R, Radin Firdaus R, Purwaningrum F (2017) Upgrading of Malaysian palm oil biofuel industry: lessons learned from the USA and Germany's policies. Cogent Food Agric 3(1):1279760. https:// doi.org/10.1080/23311932.2017.1279760

50. Economic Planning Unit Malaysia (2015) Eleventh Malaysia plan, 2016-2020: Anchoring growth on people. Prime Minister's Department http://www.sarawakdga.org.my/wp-content/uploads/ 2015/09/11th_Malaysian_Plan.pdf. Accessed 9 October 2019

51. Ministry of Energy Green Technology and Water Malaysia (2010) The national green technology policy. KeTTHA, Malaysia

52. Lady AG, Michael C (2018) Colombia biofuels annual 2018 Colombia increases biofuel blend mandate to $10 \%$. USDA Foreign Agricultural Service,

53. Bernama (2019) EU palm oil ban: PM issues new warning. Bernama. http://www.bernama.com/en/news.php?id=1708766. Accessed 4 July 2019

54. Bernama (2019) Malaysia committed to key role as biofuel technology player: Darell. The Sun Daily. https://www.thesundaily.my/ local/malaysia-committed-to-key-role-as-biofuel-technologyplayer-darell-CK905985. Accessed 4 July 2019

55. Meijaard E, Garcia-Ulloa J, Sheil D, Wich S, Carlson K, JuffeBignoli D, Brooks T (2018) Oil palm and biodiversity: A situation analysis by the IUCN Oil Palm Task Force. IUCN https://portals. iucn.org/library/sites/library/files/documents/2018-027-En.pdf. Accessed 17 July 2019

56. Bhore S (2013) Sustainable oil-palm cultivation: we need to use 'gene technology' to boost palm-oil production. Gene Tech 2: e105. https://doi.org/10.4172/2329-6682.1000e105

57. Jezeer R, Slingerland M, van der Laan C, Pasiecznik N (2019) Improving smallholder inclusiveness in palm oil production-a global review. Tropenbos International. https://www.tropenbos. org/resources/publications/improving+smallholder+inclusiveness+ in + palm+oil+production $+\%$ E2\% $80 \% 94+$ a + global+review . Accessed 6 August 2019

58. Vedaraman N, Puhan S, Nagarajan G, Velappan K (2011) Preparation of palm oil biodiesel and effect of various additives on NOx emission reduction in B20: an experimental study. Int J Green Energy 8(3):383-397. https://doi.org/10.1080/15435075. 2011.557847 
59. Abedin M, Masjuki H, Kalam M, Sanjid A, Rahman SA, Fattah IR (2014) Performance, emissions, and heat losses of palm and jatropha biodiesel blends in a diesel engine. Ind Crops Prod 59: 96-104. https://doi.org/10.1016/j.indcrop.2014.05.001

60. Nambiappan B, Ismail A, Hashim N, Ismail N, Nazrima S, Idris NAN, Omar N, Saleh K, Hassan NAM, Kushairi A (2018) Malaysia: 100 years of resilient palm oil economic performance. J Oil Palm Res 30(1):13-25. https://doi.org/10.21894/jopr.2018. 0014
61. Nambiappan B, Ismail N, Kamar Nor Aini K (2015) Competitiveness of the oil palm industry in Colombia. Oil Palm Ind Econ J 15:18-29 http://opiej.mpob.gov.my/competitivenessof-the-oil-palm-industry-in-colombia/

Publisher's Note Springer Nature remains neutral with regard to jurisdictional claims in published maps and institutional affiliations. 